\title{
U.S. Immigration Policy at a Crossroads*
}

\author{
Harriet Orcutt Duleep \\ Thomas Jefferson Program in Public Policy, College of William and Mary \\ IZA- Institute for the Study of Labor
}

\author{
College of William and Mary \\ Department of Economics \\ Working Paper Number 130
}

March 2013

* This paper, written some time ago, will be updated in a couple of months for publication in a volume. Until that time, I welcome any corrections, missed citations, or suggestions to improve the paper. The volume, to be published by Springer Science Publishers, is on recent trends in the immigration policies of major host nations including Australia, Canada, the United States, New Zealand, and some countries of the European Union. The editors are Ather H. Akbari and Martha MacDonald, both of Saint Mary's University, Canada. 
COLLEGE OF WILLIAM AND MARY

DEPARTMENT OF ECONOMICS

WORKING PAPER \# 130

March 2013

\title{
U.S. Immigration Policy at a Crossroads
}

\begin{abstract}
Two issues have taken center stage in the recent debates about U.S. immigration policy: one, illegal immigration and more generally the entrance of poorly educated individuals into the U.S. economy and two, whether the U.S. should continue its family-based admissions system or move towards a skills-based system. This paper analyzes these issues culling evidence from the history of U.S. immigration policy, the experiences of different types of U.S. immigrants, and crossnational comparisons.
\end{abstract}

JEL Classification: J15, J24, J39, J61, L26

Keywords: immigration, illegal immigration, effect on poorly educated natives, entrepreneurship, human capital investment, skill transferability, opportunity cost, learning transferability, family-based admissions, permanence

Harriet Duleep

Thomas Jefferson Program in Public Policy

College of William and Mary

Williamsburg VA 23187-8795

hduleep@wm.edu 


\section{U.S. Immigration Policy at a Crossroads}

The demise of a national-origin quota system for U.S. immigration and its replacement in 1965 with an admissions policy emphasizing family reunification opened the gates to a large and increasing flow of immigrants differing in national-origin composition from prior U.S. immigration flows. This sea change in the quantity and character of American immigration-like the waves of immigrants that arrived in the $19^{\text {th }}$ and $20^{\text {th }}$ centuries-has generated concerns about the impact of the new immigrants on the U.S. economy. Fueling the debate on whether the new immigrants are a blessing or bane are apprehensions about U.S. economic growth and an increasing wage gap between highly educated and poorly educated Americans.

Two issues have taken center stage in this debate: (1) illegal immigration and more generally the entrance of poorly educated individuals into the U.S. economy and (2) whether the U.S. should continue its family-based admissions system or move towards a skills-based system. I analyzes these issues culling evidence from the history of U.S. immigration policy, the experiences of different types of U.S. immigrants, and cross-national comparisons. Part I focuses on illegal immigration and the effect of poorly educated immigrants on the economic prospects of U.S. natives. Part II focuses on legal immigration policy and examines concerns that underlie calls to increase skills-based immigration at the expense of family-based admissions.

\section{ILLEGAL IMMIGRATION AND POORLY EDUCATED MIGRANTS}

Whether the U.S. should pursue policies to stem illegal immigration and what type of policies depends on whether illegal immigration can be stemmed and whether poorly educated immigrants (legal or illegal) hurt the economic prospects of poorly educated U.S. natives. 
A. Can the Problem of Illegal Immigration to the U.S. Be Solved?

An analysis of the unauthorized immigrant population residing in the U.S. (Hoefer et al, 2010) reveals that Mexico is the source of nearly $60 \%$ of all unauthorized migrants in the U.S. Trailing at a distance behind Mexico are El Salvador (contributing about 5\% of unauthorized migrants to the U.S.), Guatemala (4\%), and Honduras (3\%). Beyond these countries, Massey (2011) concludes:

No other country accounts for more than $2 \%$, which is the rough share comprised by Ecuador, the Philippines, Korea, and India. Brazil comes in at 1\%, as does China. The overwhelming majority of undocumented migrants thus come from Latin America, and Mexico dwarfs all other source countries, with more than twelve times the number of undocumented migrants as the next largest contributor.

Mexican immigrants are typically poorly educated; they are much more likely than U.S. natives, and almost all other immigrant groups, to lack a high-school degree. Within the Mexican immigrant population in the U.S., illegal immigrants have lower levels of schooling than legal immigrants (e.g. Rivera-Batiz, 1999). One could thus surmise that the problem of illegal immigration - and more generally the immigration of poorly educated individuals — stems from our shared border with Mexico, and that these issues would disappear with demographic and economic changes in our south-of-the-border neighbor.

A country's age distribution is a potent predictor of streams of potential immigrants; ${ }^{1}$ most adult immigrants are young. ${ }^{2}$ Another key predictor of migratory streams is a country's level of economic development. At the very lowest levels of economic development, people do

\footnotetext{
${ }^{1}$ Theoretically, the younger migrants are, the longer the payoff time from migration; opportunity costs also increase with age - as one works in a particular locality and firm, it becomes increasingly difficult to transfer the accumulated work experience.

${ }^{2}$ The age pattern of migration is well documented. See, for instance, U.S. Census Bureau (1996) and Fertig and Schmidt (2001).
} 
not migrate: When a certain economic threshold is passed, migration from poor to rich regions begins. $^{3}$ Once started, the migration persists, following the networks and paths of earlier migrants. As the source-country/destination-country differential in economic development narrows, migration decreases.

Demographically and economically Mexico is changing, and those changes will decrease (and are decreasing) the U.S. immigration of low-educated individuals, legal or illegal, from Mexico. It would be premature, however, to conclude that illegal immigration and more generally the migration to the U.S. of the poorly educated will disappear with declines in Mexican immigration. History teaches us that when one source of unskilled labor stops, another begins.

Consider the U.S. history of migrant labor to support West Coast agriculture. Before the heavy reliance on Mexican workers, Asian immigrants filled this labor demand. At first, and until the 1890's, the immigration was almost exclusively from China; during the peak years of Chinese immigration, 97 percent of the immigrants reported having worked as unskilled laborers in China. ${ }^{4}$ When the 1892 Chinese Exclusion Act restricted their immigration, Indians, Koreans, and Japanese immigrants filled the void: during the peak years of Korean and Indian immigration, 96 percent of Korean immigrants, and 85 percent of Indian immigrants reported laborer as their country-of-origin vocation. The Immigration Act of 1924 barred Asian laborers from the United States. It did not, however, restrict immigration from the Philippine Islands, which were, in 1924, a U.S. territory; the demand for unskilled Filipino labor increased

\footnotetext{
${ }^{3}$ A few examples of research documenting this relationship include Hatton and Williamson (1992, 1994), Massey and Zenteno (1999), and Volger and Rotte (2000).

${ }^{4}$ Records from the former Immigration and Naturalization Service were used to compile these statistics. See Table 2.3 and Appendix A of Duleep (1988). The percents refer to the percent of immigrants who report an occupational background.
} 
precipitously. With commonwealth status granted to the Philippines in 1934, Filipinos became aliens for immigration purposes and the Filipino surge ended. Asian immigration ceased and Mexicans began to fill the shoes of the banished Asian laborers.

If past is prologue, when Mexico resigns its U.S. post as number-one source of poorly educated labor, other groups will fill the void. Thus the issues of illegal immigration and the immigration of the poorly educated will likely extend beyond the current situation. Lessons learned from the Mexican/U.S. story may help guide the way.

One lesson from the U.S.-Mexican story is that legal and illegal immigration are closely intertwined. With the Bracero program, begun in 1942, Mexican workers entered the U.S. labor market with temporary permits. The program's purported purpose was to control illegal immigration. Later, a key concern in ending the program was that illegal immigration would increase (Congressional Research Service, 1980). A 1963 note by the Mexican Ambassador to the U.S. underscores the legal/illegal immigration nexus:

It is not to be expected that the termination of an international agreement governing and regulating the rendering of service by Mexican workers in the United States will put an end to that type of seasonal migration. The aforesaid agreement is not the cause of that migration; it is the effect or result of the migratory phenomenon. Therefore, the absence of an agreement would not end the problem but rather would give rise to a de facto situation: the illegal introduction of Mexican workers in the United States.... (Congressional Research Service, 1980, p.55).

The Mexican Ambassador's prediction proved prophetic. With the Bracero program in place, illegal immigration from Mexico was not a problem. When the Bracero program ended, illegal immigration took off, and then soared, becoming a fixture on the U.S. immigration scene until legal pathways were once again restored.

In 1976, Congress had quietly reinstated temporary worker migration under the H-visa program, but the number of such visas issued to Mexicans remained small until 1996... temporary worker migration surged in the late 1990s... and then surged again after 2005. (Massey, 2011, p. 9) 
...legal immigration and guest worker immigration from Mexico have [now] both risen to record levels, with temporary legal entries from Mexico averaging 331,000 per year and entries of legal permanent residents around 178,000 per year. As in the late 1950s, therefore, the United States is taking in roughly 500,000 Mexican migrants per year in legal status and undocumented migration has virtually disappeared. (Massey, 2011, p. 21)

This section began with the question — can the problem of illegal immigration be solved? The answer is clearly yes. Massey's analysis shows that when legal pathways are provided, undocumented immigration ceases and becomes legal immigration.

Yet the central issue is not illegal immigration per se. It is, and always has been, whether poorly educated immigrants hurt the economic prospects of poorly educated Americans. This question influenced the Bracero Program's initiation, reform, and demise. It is the question that dominates discussions of whether and to what extent the U.S. should encourage or discourage the immigration of poorly educated individuals.

Massey's analysis may suggest to some that the U.S. could either have a large guest worker program/expanded legal immigration from Mexico, or undocumented immigration from Mexico: Sans legal pathways, illegal immigration will exist. If this were true, then whether the immigration of poorly educated immigrants hurts poorly educated natives would be irrelevant as the U.S. would have poorly educated immigrants regardless of its policies.

A careful reading of the analyses of Massey and fellow researchers of the Mexican Migration Project data ${ }^{5}$ reveals, however, that undocumented immigration is responsive to enforcement measures. With greater enforcement, the entry points of illegal immigrants change; with greater enforcement, the undocumented are less likely to return to Mexico (Massey, 2011).

\footnotetext{
${ }^{5}$ The Mexican Migration Project is a bi-national study that annually surveys Mexicans in the U.S. and in Mexico. The information is added to a cumulative database focused on the lives of documented and undocumented migration (http://mmp.opr.princeton.edu/).
} 
These findings suggest that, even in the absence of legal pathways, the U.S. could stop illegal immigration with sufficiently comprehensive enforcement efforts. But would the expenditures and restrictions be justified? The answer depends on whether the immigration of poorly educated individuals hurt the prospects of poorly educated natives.

B. Does the Immigration of Poorly Educated Migrants Hurt Poorly Educated Americans? Theoretical Perspectives

Theoretically, the answer would appear to be an unequivocal "yes." Increase the supply of unskilled labor and the wages of unskilled Americans will fall, or their unemployment increase, or both.

Stepping back a bit, however, reveals that the theoretical prediction that an increase in unskilled immigrant labor must necessarily harm the employment and wages of native unskilled labor comes from a tendency to think in terms of two types of labor — skilled and unskilled. Data from nationwide surveys such as the census or the Current Population Survey, which categorize individuals by their occupation and industry, reinforce this perspective. Nevertheless, within the same observationally equivalent job category a variety of attributes exists that make people substitutes or complements. These points are underscored in the studies of Muller and Espenshade (1985), Bailey (1987), Gallo and Bailey (1996) and more recently in Sanders (2011), Peri and Sparber (2009), and Ottaviano and Peri (2006).

Via case-study research, Bailey (1987), Gallo and Bailey (1996), and others show that immigrants and natives with the same census occupation/industry category are distinguished by the nature of their work and the processes by which they become employed, trained, and promoted: 
Due partly to reliance on networks, immigrants are concentrated in industries (in both skilled and unskilled jobs) characterized by informal training and employment processes. More structured and formally organized industries make relatively less use of social networks for hiring (although they continue to be important). Thus, while immigrants were concentrated in the low-skilled positions of the full-service restaurant and in the immigrant restaurant sectors, low skilled natives were concentrated in the more formally organized fast-food and chain restaurant sectors; while immigrants populated the small food retail shops, low skilled natives are concentrated in large supermarkets; and while immigrants are concentrated in the nonunionized renovation sector in the construction industry, native minorities are in the unionized and more established construction firms. To a significant extent the role of networks in job and in informal specific skill acquisition differentiates low-skilled immigrants from low-skilled native workers in the secondary labor market, first by channeling immigrants into distinctive occupational sectors, and second by giving opportunities for skill acquisition that low-skill native workers find in institutionalized and formal skill learning programs. (Gallo and Bailey, 1996, pp. 206-7)

From a detailed analysis of the impact of immigrants on the California labor market,

Muller and Espenshade (1985, pp. 101-102) conclude:

The evidence considered thus far points to the conclusion that the influx of Mexicans to Los Angeles and southern California during the 1970's did not increase the aggregate level of unemployment among non-Hispanic California residents, including blacks..... The reason for this, at least in southern California, is that there appears to be relatively little direct competition between Mexican immigrants and native blacks for the same jobs.... these workers are labor market complements rather than substitutes.

Employers also respond to labor force changes (Duleep, 2012a) and these responses may minimize or even improve the employment and wage picture of U.S. natives. Businesses may develop or persist in response to the availability of certain types of labor that particular immigrant groups provide (Enchautegui, 1995; Manson, Espenshade, and Muller, 1985). Enchautegui (1995) finds that opportunities for low-skilled employment improve with lowskilled immigration. Similarly, Lewis (2007) finds that firms respond to immigration by altering the capital/labor mix of their production:

Over the past thirty years, U.S. manufacturing plants invested heavily in automation machinery.... these investments substituted for the least-skilled workers and complemented middle-skilled workers at equipment and fabricated metal plants... some metropolitan areas experienced faster growth in the relative supply of less-skilled labor in the 1980s and 1990s due to an immigration wave and the tendency of immigrants to regionally cluster. Plants in these 
areas adopted significantly less machinery per unit output, despite having similar adoption plans initially.

Other interactions challenge a priori predictions about the effect of poorly educated immigrants on the economic opportunities of poorly educated natives. Beyond the relationship between native and immigrant labor in production, the economic effect of immigration on native labor will depend on how immigrants affect the demand for products produced by natives. Although this effect has been noted in the literature (Altonji and Card, 1991; Muller and Espenshade, 1985), immigrant consumption patterns are rarely studied. ${ }^{6}$ Immigration may also affect the demand for products produced by natives through a variety of routes. Immigrants spend money and buy native-produced products. The incomes of natives will also be affected by the extent to which the products produced by immigrant and native labor are substitutes or complements. If the presence of immigrants makes one product cheaper, the demand for complementary products will increase. There is also an interplay between immigrant/native relationships in production and consumption effects. The availability of immigrants to tend kids and clean homes allows middle-class women to work and spend money on goods and services that may be produced by low-educated native-born labor.

Because of these and other issues, whether the immigration of poorly educated individuals harms poorly educated U.S. natives is, above all, an empirical question. Given the variety of potential outcomes, we would like to know whether on average the immigration of poorly educated immigrants harms the economic prospects of poorly educated natives. We would also like to know whether and how such effects vary by type of admission policy.

${ }^{6}$ Historical studies of immigrant consumption patterns include Haines (1989) and Modell (1978). 


\section{Does the Immigration of Poorly Educated Migrants Hurt Poorly Educated Americans? Empirical Perspectives}

It is undoubtedly true that the availability of the large supply of recent immigrant labor has prevented the increase in wages which otherwise would have resulted... (Jencks and Lauck, 1926, p. 207)

There is absolutely no statistical proof of an oversupply of unskilled labor resulting in a displacement of native by immigrant laborer. (Hourwich, 1922, p. 11)

The above quotes, used by Hatton and Williamson $(1995, \mathrm{p} .1)$ to illustrate the varied conclusions that characterized empirical studies of the early 20th century, might just as easily been pulled from the transcripts of recent congressional hearings on whether and how U.S. immigration policy should be reformed. Despite extensive empirical research, there is still no decisive answer as to whether poorly educated immigrants hurt, help, or have no significant effect on the employment and wages of poorly educated natives.

Generally speaking, studies on this issue can be divided into two methodological camps. Cross-area studies measure the impact of immigration on native-born economic status by comparing natives' wages and employment in areas with varying levels of immigration; these studies do not generally find a negative immigration effect on natives that is important and statistically significant. Aggregate studies estimate the effect of immigrants on natives' earnings at a whole economy level; these studies find a large and statistically significant negative effect of immigration on the wages of U.S. natives with low levels of schooling. The following discussion argues that neither methodology can yield a definitive answer as to whether and how influxes of poorly educated immigrants affect the economic status of poorly educated natives, and then proposes an alternative. 


\section{Cross-Area Studies}

Cross-area studies have been critiqued on a number of grounds. The most recent critique is that they suffer from attenuation bias (Aydemir and Borjas, 2011). Immigration measured at a regional level, particularly from survey data, is measured imprecisely. This downward biases the estimated effect of the independent variable, which is an area-specific measure of immigration or change in immigration.

Analysts should, however, disaggregate the immigration variables. At the most basic level, the potential for immigrants and natives to be complements or substitutes depends on their human-capital endowments and in particular their levels of education and experience (Gang and Rivera-Batiz, 1994; Lewis, 1994). It is thus critical to measure the effect of changes in the entrance of poorly educated immigrants on the economic status of poorly educated natives. But disaggregation is problematic for cross-area studies because the more the immigration variable is disaggregated, the worse attenuation bias becomes.

Cross-area studies also suffer from endogeneity bias. Immigrants may choose areas with better than average economic opportunities thus obfuscating any potential adverse immigration effect on the economic status of natives in those areas. A potential solution is to first difference: relate changes in native-born economic status to changes in immigration. Simultaneity still persists, nevertheless, if immigrants are more likely to move to areas where wages (or employment opportunities) are increasing and less likely to move to areas where wages are declining.

To address the simultaneity problem, researchers instrument the change in the fraction of immigrants in an area: a proxy for the original variable is chosen that is not affected by changes 
in native-born wages and employment at time $t$ but is highly correlated with the explanatory variable of interest - the change in the fraction of immigrants at time $t$.

Beyond overcoming the simultaneity problem, the success of the instrumental variable procedure depends on how well it captures variations in the explanatory variable. If the instrumental variable and the original variable are not highly correlated, then the estimated effect will be imprecise. Though moderately successful in instrumenting changes in the fraction of immigrants, researchers have been much less successful in instrumenting changes in the fraction of poorly educated immigrants; the estimated effects often preclude any conclusion about the effect of poorly educated immigrants on the earnings of poorly educated natives. ${ }^{7}$

To break the reverse causal link between economic conditions (or changes in economic conditions) and immigration (or changes in immigration) analysts have turned to natural experiments. Card (1990) examined the unemployment and wages of low-skilled blacks and other non-Cuban groups in Miami before and after the Mariel boatlift (composed primarily of Cubans with lower than average levels of schooling), and found no effect. ${ }^{8}$ Nevertheless, we may be limited in pursuing this approach by the paucity of appropriate natural experiments and by the special circumstances that accompany them. ${ }^{9}$ A more general approach is desirable in our

\footnotetext{
${ }^{7}$ For instance, in the Altonji and Card (1991) study, the correlation between the fraction of immigrants in 1970 and the change in the fraction of immigrants in the SMSA is .60. In a supplementary analysis, Altonji and Card instrument the change in the fraction of less-skilled immigrants, by regressing it on the fraction of less-skilled immigrants in the SMSA population. In contrast to the moderately high correlation between the fraction of immigrants in 1970 and the change in the fraction of immigrants, the correlation between the fraction of less-skilled immigrants in 1970 and the change in the fraction of less-skilled immigrants by SMSA is only .27. Using this instrument to estimate the effect of less-skilled immigration on the wages of low-educated natives, they find that the magnitude of the estimated negative effect is larger than when the overall immigration variable is used. Yet, the estimated effect is very imprecise, precluding any conclusion as to whether the potentially important estimated effect of "less skilled" immigration on the wages of less-skilled natives reflects a real effect or simply random variation.

${ }^{8}$ Hunt (1992) is another example of a study that exploits a natural experiment.

${ }^{9}$ It may not be appropriate, for instance, to generalize from the estimated effect of refugees on native-born wages and employment since refugees differ in their economic assimilation from other immigrants. Studies contrasting
} 
quest to measure how the entrance of poorly educated immigrants affects the economic status of poorly educated natives.

A third problem plaguing cross-area studies is that natives may migrate in response to immigrant inflows. According to this scenario, immigrants reduce (or are expected to reduce) the wages and employment opportunities of natives, and natives leave. No wage or employment effect, or small effects, are observed because native outmigration has reduced the supply of native-born labor in areas of high immigration.

Many studies have examined whether poorly educated natives do or do not migrate in response to immigration, and the conclusions vary. Yet, even if a migration effect is found, it isn't necessarily relevant to the question we are seeking to answer - does the immigration of poorly educated immigrants adversely affect the economic status of poorly educated natives? Rates of immigration and native out-migration could be correlated for reasons that have no relevance at all to the employment and welfare of low-educated natives. Consider the following scenario.

With the exception of Chicago, the destinations immigrants have historically chosen are large cities in coastal states such as California and New York. ${ }^{10}$ Immigrants are attracted to these areas because of immigrant communities, employment opportunities, and other forms of social and material support through well-established immigrant networks in these locations (Massey, 1990). ${ }^{11}$ Highly educated natives may move to the same areas that immigrants have

refugee economic assimilation to that of other immigrants include Chiswick (1979, 1980), Gallo and Bailey (1996), and Fix and Passel (1994).

\footnotetext{
${ }^{10}$ Historically, most immigrants have located in a small number of destinations. Fix and Passel (1994, p. 29) concluded that 93 percent of the foreign-born population lived in metropolitan areas in 1990 and that slightly over half of the immigrants entering in the 1980's went to California and New York.

${ }^{11}$ Bartel (1989) and Altonji and Card (1991) find that immigrant inflows are positively correlated with the
} 
traditionally favored because of employment opportunities and because these areas are cultural centers, ethnically diverse, and have other attributes that are attractive to highly educated individuals. At the same time, these cities share the problems of all big cities-crime, poor public schools, drug marketing - that grew over time alongside increases in immigration. The highly educated insulate themselves from these problems by sending their kids to private schools and buying housing that is protected from crime. Low-educated natives may move out of these areas — not because they have experienced any adverse economic effect of immigration—but because of urban problems they cannot insulate themselves from.

Studies that find there is a native-born response without simultaneously examining whether the economic status of natives is affected are not really relevant to the question we seek to answer. The fact that one finds a correlation does not mean that it is harmful. In order to have relevance, the migration response must be simultaneously incorporated into the measurement of natives' economic status.

\section{Aggregate Studies}

The possibility that natives may migrate in response to immigration and the issue of endogenous immigration location choice has led several researchers to reject the use of crossarea variation in immigrant concentrations to estimate the impact of immigration on native labormarket outcomes. Instead, these researchers estimate the effect of immigrants on natives' earnings at a whole economy level (e.g. Borjas, Freeman, and Katz, 1992, 1996, Jaeger, 1996 and Hatton and Williamson, 1995).

immigrant fraction of an area's population. 
A whole-economy approach captures the potential effects on natives' earnings of migration responses by natives within the nation. Another positive trait of these studies is an emphasis on measuring the effect of increases in poorly educated immigrants on the earnings of poorly educated natives. These studies find a large negative effect of immigration on the wages of natives with low levels of schooling.

The overwhelming problem with these studies is that in aggregate, many factors (either as levels of changes) move together or apart and statistically significant relationships may be found, but there simply isn't enough information to ferret out causal relationships. For instance, U.S. poverty rates declined from 1959 to 1973 . This decline nicely coincides with declines in legal entries (temporary migrants and legal immigration) from Mexico. As such it would not be surprising to find a statistically significant and strongly negative effect of influxes of poorly educated immigrants on the economic status of poorly educated U.S. natives. Yet many other factors - other than the decline in legal low-skilled immigration - that preceded or occurred during this period could explain the declines in poverty. ${ }^{12}$

\section{A Shortcoming of Both Methodologies}

In summary, two central approaches, that generally reach diametrically opposing conclusions, have been used to measure the effect of poorly educated immigrants on poorly educated natives. Both are problematic. With the cross-area studies, a failure to find a negative

\footnotetext{
${ }^{12}$ Moreover, declines in legal immigration often coincide with increases in illegal immigration and vice versa (Massey, 2012). The strong negative impact of poorly educated immigrants on poorly educated U.S. natives would likely not be found if a total measure of low-skilled entries, including the undocumented, were used. This would not mean there is no effect. It only illustrates the problem with ferreting out causality with nationwide aggregate trends.
} 
effect does not mean there isn't an effect. With the aggregate studies, a large and statistically significant effect may be found, but does it mean anything?

Both approaches also share a shortcoming. Whether and to what extent U.S. natives are harmed (or helped) by poorly educated immigration may depend on the admission program through which immigrants enter the U.S. In deciding whether to allow or even encourage the immigration of poorly educated individuals, it would be helpful to determine what type of entry_illegal, legal kinship-based, legal employment-based or legal temporary_least harms, or most benefits, poorly educated natives.

It is difficult to see aggregate time series analyses could address this issue. Cross-area analyses, with greater variation at their disposal, offer more hope. Nevertheless, dividing up the independent variable - immigration of the poorly educated - by type of immigration, would exacerbate the attenuation bias problem. Moreover, the instrumental variable approach used to conquer the endogeneity problem in cross-area studies uses variation in why immigrants migrate to certain areas - some migrate not for economic reasons but because members of their group have migrated there before, to create an instrument. However, such an IV approach renders cross-area analyses useless for measuring the potentially differential effects on poorly educated natives of poorly educated immigrants admitted via different admission programs.

\section{A Different Approach}

Were it not for the problems associated with the cross-area approach, researchers would not choose to throw away so much information in favor of aggregate studies. Rather than going the aggregate route, let us return to the drawing board and see if we can develop a 
straightforward approach that uses micro data to determine whether the immigration of poorly educated individuals hurts the economic prospects of poorly educated natives.

The cross-area analytical approach attempts to measure the impact of immigration on natives' economic status by comparing natives' wages and employment in areas with varying levels of immigration. The analyst asks: does the entry of poorly educated immigrants into areas affect the economic prospects of poorly educated natives in those areas?

Since we are trying to measure the effect of changes in immigration on natives' economic status, "changes in immigration" is an independent variable in the regression. Three problems arise from using changes in immigration (or immigration) as the independent variable: attenuation bias - is the estimated coefficient on changes in immigration biased downward because of measurement error? Simultaneity — to what degree is our estimated effect picking up the effect of changing economic conditions on changes in immigration as opposed to the effect of changes in immigration on changes in natives' economic status? And native out-migrationthere is no way to measure the economic status of those who have moved out of areas with immigrant influxes.

Yet the question we are really trying to answer is: do poorly educated natives who live in—or have lived in—states or areas that experienced influxes of poorly educated immigrants do worse than poorly educated natives who have not lived in states or areas that have not experienced influxes of poorly educated immigrants? Asking the question in this way leads to a straightforward approach that uses individual data and avoids all of the pitfalls associated with the cross-area studies.

The regression model, which would be run on poorly educated natives, is: 
$\mathrm{y}_{\mathrm{i}, \mathrm{t}}-\mathrm{y}_{\mathrm{i}, \mathrm{t}-1}=\alpha+\beta_{1} \mathrm{~L}_{\mathrm{i}, \mathrm{t}-1}+\beta_{2} \mathrm{Z}_{\mathrm{i},}+\mathrm{A}^{\prime} \gamma+\varepsilon_{\mathrm{i}, \mathrm{t}}$

where

$\mathrm{y}_{\mathrm{i}, \mathrm{t}}-\mathrm{y}_{\mathrm{i}, \mathrm{t}-1}=$ the change in earnings or wages of individual $i$ from time $\mathrm{t}-1$ to time $\mathrm{t}$.

$\mathrm{L}_{\mathrm{i}, \mathrm{t}-1}=1$ if native-born person $i$ lived in an area in year $\mathrm{t}-1$ that experienced an influx of poorly educated immigrants, even if he or she moved away from this area and now lives in another area in year $\mathrm{t}$.

$=0$, otherwise.

$\mathrm{Z}_{\mathrm{i},}=$ individual characteristics of native-born person $i$ such as detailed years of schooling and age

$\mathrm{A}=$ trend in wages, unemployment and other indicators that affect the economic prospects of the poorly educated for the area that individual i lived in year t-1

With this approach "changes in immigration" is no longer an independent variable. We still need information on which areas experienced influxes of poorly educated immigrants so as to identify poorly educated natives who have or have not lived in such areas. However, attenuation bias is not an issue because we are no longer estimating the effect of changes in immigration.

Once areas are identified as those that had an influx of poorly educated immigrants in year $\mathrm{t}-1$ versus those that did not, then the sample individuals who lived in an area in year $\mathrm{t}-1$ experiencing an immigration influx in year t-1 can be identified. By including persons who lived in such an area in year $t-1$, but moved and live elsewhere in year $t$, our estimate will include potential economic harm to persons who moved from an area that experienced an influx of poorly educated immigrants. Such an approach is eminently feasible since data sets such as the 
Current Population Survey provide information on where individuals lived a year ago and permit following the earnings of individuals by matching consecutive-year data. ${ }^{13}$

Since we are not estimating the effect of changes in immigration on changes in native economic status, we do not need to use instrumental variable estimation to deal with endogeneity bias. To the extent that immigrants move to areas of high economic growth, the estimated effect of our variable of interest, "L," will reflect this. The solution, however, is to add to the estimation area- and time-specific variables that precisely control for varying economic conditions that affect poorly educated natives rather than using instrumental variable estimation with all its attendant problems.

There are several advantages to pursuing the above analysis not in the regression format shown above, but with the analysis of numerous natural experiments, in multiple time periods, in which the treatment is living in an area in $\mathrm{t}-1$ that experienced an influx of immigration and the control is not living in an area that experienced an influx of immigration. ${ }^{14}$ Testing on numerous paired sites, in multiple time periods, would facilitate exploring how any immigration effect differs depending on the level of economic conditions for poorly educated individuals and how an immigration effect might vary depending on the admission policy (family, occupational, temporary, or illegal) poorly educated immigrants entered in. We should be able to find multiple treatment and control sites that precisely match on economic grounds, but differ in terms of

\footnotetext{
${ }^{13}$ Matched administrative record-survey data permit following individual earnings and residence over many years. Decennial census data provide information on where persons lived a year, and five years ago which could be used in conjunction with data on natives' earnings in year t. There are not longitudinal earnings data on decennial census data. There are, however, panel data on labor force participation that could be usefully exploited (Duleep and Sanders, 1994).

${ }^{14}$ Refer to Duleep (2012) for ways to increase the precision and robustness of the estimated effects.
} 
immigration, given that immigrants in many groups don't automatically go to high-growth areas, but gravitate towards areas that immigrants in their group already live in.

The strategy outlined above would, I believe, yield definitive information about how influxes of poorly educated immigrants affect the economic status of poorly educated natives.

\section{E. Policies to Promote the Economic Mobility of Poorly Educated Immigrants}

If it is determined that the immigration of poorly educated immigrants does not hurt the economic prospects of poorly educated U.S. natives, then thought must be given to what policies would best promote the economic mobility of poorly educated immigrants.

Economic mobility would be promoted by policies that promote investment in human capital. Whether immigrants invest in American human capital will be affected by whether they intend to stay in America. Starting a business, pursuing jobs with on-the-job training and learning English take time and money and generally result in lower earnings at first. Immigrants would embark on these pursuits only if the benefits from making them could be reaped in the future. Expected permanence in the U.S. is thus an essential building block for promoting immigrant investment in U.S.-specific human capital.

Empirical light can be shed on the importance of permanence by exploiting two definitions of year of immigration available in matched CPS-Social Security data (Duleep and Dowhan, 2002a). The CPS year-of-immigration measure is based on the question "When did you come to the U.S. to stay?" The question suggests permanence in the United States. From the longitudinal Social Security earnings files, the year individuals first earned in the United States can be identified. With these two pieces of information immigrants can be divided into 
those whose first U.S. earnings coincide with an intent to stay permanently, and those who earned in the U.S. for several years, before deciding to stay permanently. When this is done, a clear difference emerges between the groups: Immigrants whose first earnings coincide with an intent to stay have much higher earnings growth and by implication a higher propensity to invest in human capital. ${ }^{15}$

There are also intergenerational implications of permanence. Historically, groups that were permanently attached to the U.S. showed greater intergenerational progress in educational attainment than groups who were less permanent and changes in permanence have been accompanied by changes in educational attainment. A likely reason for this is that educational expectations are tied to the place that one is attached to. If a significant part of the community is tangentially attached to the U.S., as would be the case in communities where a large percentage are going back and forth, then expectations for their children's education will be influenced by the "home" country.

For poorly educated immigrants, programs that foster long-term investment in human capital and permanence as opposed to temporarily filling labor shortages are more likely to foster upwardly mobile immigrant communities. Possible conflicts could occur, however, between policies to decrease harmful immigration effects on U.S. natives and policies to promote the economic mobility of poorly educated immigrants. Piore, for instance, argues that it is the temporary nature of some immigration that permits immigrants to take jobs that would otherwise be viewed as undesirable ${ }^{16}$ : Determining the best policy mix rests on getting a better handle on whether and how poorly educated immigrants affect the economic status of poorly educated natives.

\footnotetext{
${ }^{15} \mathrm{~A}$ similar finding emerges for immigrant women (Duleep and Dowhan, 2002b).

${ }^{16}$ A similar argument is voiced in interviews with employers in the hotel industry as to why natives do not apply for jobs held by immigrants (Waldinger, 1996).
} 


\section{SHOULD THE U.S. DECREASE FAMILY-BASED IMMIGRATION AND INCREASE SKILLS-BASED IMMIGRATION AND, IF SO, HOW?}

For nearly half a century, family unification has been the cornerstone of U.S. immigration policy. The Immigration Act of 1965 eliminated country-specific quotas and created a system of restricted and non-restricted immigrant admission categories favoring applicants with family members in the United States. Under this law, in effect until 1990, spouses, minor children, and parents of U.S. citizens were admitted without regard to numerical limitations. Of the numerically restricted visas, 80 percent were reserved for the adult children and siblings of U.S. citizens (as well as their spouses and children) and for the spouses and children of legal permanent resident aliens. Only 20 percent of the numerically restricted visas were allocated to an occupational-skills category that included two parts—one part rewarding applicants in occupations for which labor is deemed scarce (skilled and unskilled); the other rewarding professionals with advanced degrees or persons of exceptional ability. ${ }^{17}$

Several U.S. immigration policy experts, such as Barry Chiswick (1981), have for years pushed for an immigrant admissions system that is more skills based. A small move in that direction occurred with the 1990 Immigration Act, which among other things, increased admissions on the basis of occupational skills. The general belief that immigrants admitted on the basis of occupational skills are more economically productive than immigrants admitted via family ties was an important motivation for increasing occupation-based immigration. This reform was not sufficient, however, to alter the essentially family-based nature of U.S. immigration (Lowell, 1996).

In 1997, the U.S. Commission on Immigration Reform, mandated by the 1990

\footnotetext{
${ }^{17}$ This taxonomy is approximate and leaves out several categories.
} 
Immigration Act, issued a report recommending that spouses and minor children of U.S. citizens continue to be given first priority in the U.S. immigration system. Yet, in a sharp shift from the decades-old family-based immigration policy, the Commission recommended eliminating two kinship categories: the siblings of U.S. citizens and the adult children of U.S. citizens and legal permanent residents. Under the proposed system, those relatives could not obtain U.S. visas unless they qualified because of specific job skills.

The debate about whether to adopt a less family-based system continues to this day. Mostly split along party lines, Democrats, such as the late Ted Kennedy, argue that expanding employment-based immigration at the expense of family-based immigration is inhumane. Republicans counter that the emphasis on kinship-based immigration makes the U.S. less competitive with other immigrant receiving nations. For instance, Senator John Cornyn (Republican from Texas) argues that most legal immigrants enter the country via a family-based preference, and as such have no bearing on national competitiveness.

Proposals to increase immigrants' skill levels often advocate doing so by expanding the current visa category designed to fill specific employment needs: Under George W. Bush, the White House proposed eliminating visa categories that allow immigrants in the U.S. to bring over adult children, siblings, and potentially parents and replace them with visas giving preference to skilled workers sought by employers. Other proposals, such as one promoted by Mitt Romney, suggest reducing family immigration and increasing immigrant skill levels using more general definitions of skill such as education or an ability to contribute to the U.S. economy. 


\section{A. Inadvertent Consequences of Removing Family Admission Categories}

The immigration policy debate that rages in the U.S. is presented as a dichotomy: Should the U.S. continue its primarily kinship-based admission policy or adopt instead a point system that rewards needed skills?

Family visas are, however, an important complement to high-skilled visas; skilled immigrants have families too. In considering which country to move to, will an emigrating scientist be more likely to move to a country where his family members, including siblings, parents, and adult children, can also live, or to a country where only certain family members are welcome? Would Einstein have continued to live in the U.S. had he not been able to bring over his sister Maja? A family-friendly policy may be one reason the U.S. has been able to attract immigrants with stellar qualifications.

Using U.S. Immigration and Naturalization Service data on admissions criteria matched to 1990 Census data, Duleep and Regets (1996b) explored the association between admission criteria and immigrant education levels by relating the percent of immigrants admitted on the basis of occupational skills in year-of-immigration/country-of-origin cohorts to the education levels of immigrants in those cohorts. Not surprisingly—given that one of the occupational skills' categories admits professionals, scientists, and artists of exceptional ability ${ }^{18}$-immigrant education levels were found to be positively correlated with the percent of immigrants admitted on the basis of occupational skills. Surprisingly, however, there was also positive and significant relationship between immigrants' education levels and the percent of immigrants admitted as siblings. An interpretation of this finding is that immigrants who gain admission on the basis of

\footnotetext{
${ }^{18}$ The other occupational skills category admits workers, skilled and unskilled, in occupations for which labor is deemed scarce in the United States.
} 
occupational skills are followed by their siblings, who gain admission via the siblings' preference. If those who enter on the basis of occupational skills are highly educated, it is likely that their siblings are also highly educated.

Separating the analysis by region of origin revealed strongly positive associations between education and percent admitted via the siblings' preference for Asia and Central and South America, but not for Europe. Driving this result may be limited employment opportunities for the highly educated in countries that are less economically developed than the United States. A college-educated brother or sister of a French or German immigrant in the United States would be less likely to emigrate to the United States than the college-educated sibling of an Indian or Mexican immigrant because the employment opportunities for the highly educated in France or Germany resemble those in the United States, whereas such opportunities may be more limited in India or Mexico. ${ }^{19}$

These results suggest that eliminating family admission categories, such as the sibling category, may inadvertently work against the goals associated with a system giving greater relative weight to occupational skills or education.

\section{B. Limitations of the Occupation-based Admission System}

There are also inherent problems with the occupation-based admission system (alternatively called the occupational-skills, employment-based or fill-the-gap admission system) that should give pause to those who favor expanding it to increase immigrant skill levels.

Tailoring immigration to labor shortages is theoretically appealing, but difficult in

\footnotetext{
19. Limited employment opportunities for the highly educated in economically developing countries refer not only to unemployment or underemployment among the highly educated but also to the nature of employment.
} 
practice. In the employment-based immigration system, a shortage is defined by an employer's willingness to participate in a sometimes cumbersome labor certification process. The purpose of this process is to show that the employer can not find a U.S. native or legal resident to fill a position. Such a process requires a bureaucracy to oversee it. Nevertheless, the bureaucratic oversight may be meaningless as there is no way to insure that employers really cannot find prospective employees and are not simply using the occupational-skills immigration avenue to depress the wages of U.S. natives in those occupations.

Lindsay Lowell $(1996,362)$ comments:

Skill-based immigrants, in part because their admission depends on formal links to U.S. employers... may enter directly into job competition with U.S. workers... Conversely, the nature of the jobs that are initially filled by family-based immigrants, precisely because they are not as tightly linked to the primary labor market may mean that family-based immigrants compete less with U.S. workers.

Sorensen's (1996) study backs Lowell's insight and casts doubt on the efficacy of the bureaucratic oversight of employment-based immigration. Using census data matched to immigrant admissions data, she found that immigrants admitted on the basis of occupational skills (employment-based immigrants) have a statistically significant negative effect on the employment opportunities of native-born white males. In contrast, family-preference immigrants have a statistically significant positive effect on the earnings and employment of U.S.-born whites and on the earnings of U.S.-born blacks.

The existing bureaucratic solution of using immigration to fill specific employer needs also likely favors established firms that have the wherewithal to wade through the bureaucratic process. It may also favor employers with political pull. Yet it is young firms that are the greatest job creators. Moreover, things change and in the relatively unfettered U.S. economy, things can change quickly, a dynamic that usually serves the U.S. well. Today's must-have immigrant with 
such-and-such specific skills may be yesterday's news before the ink on the necessary paperwork has dried.

\section{Taking a Longer Perspective on Immigration and the U.S. Economy}

Rather than looking at immigration as a mere palliative for filling gaps, why not instead pursue a policy that encourages the immigration of individuals who would contribute to the longrun vitality of the U.S. economy?

Economic growth is critical to the jobs and wages of U.S. natives. A voluminous literature points to innovation being the key ingredient of economic growth. To innovate is to introduce something new, such as a new method or product. In the U.S. market economy, entrepreneurship is a principal route through which innovations occur. But what facilitates entrepreneurship?

In deciding whether to develop a new product or service, existing businesses and potential entrepreneurs examine the costs and returns of pursuing such an activity. Returns are affected by the potential demand for a new product or service. In addition to capital outlays, a crucial cost of any new venture is training the workforce that will create the new product or service. New, and changing, businesses require people who are willing and able to acquire new human capital. To insure the long-run vitality of the U.S. economy, the most important attribute is an immigrant's propensity to learn new skills, whether in response to the needs of emerging or changing businesses, or starting a new business.

By the very nature of their admission, employment-based immigrants have specific skills that immediately transfer to the United States. Because they enter to fill specific jobs - and are 
paid accordingly - employment-based immigrants would have no more incentive than U.S. natives to invest in new human capital. In contrast, kinship-based immigrants—precisely because they lack specific skills that are immediately valued by the U.S. labor market—will have a higher propensity to invest in new human capital than either U.S. natives or employment-based immigrants with comparable levels of schooling. This prediction flows from a simple Immigrant Human Capital Investment (IHCI) model developed by Duleep and Regets (1999, 2002).

The IHCI model builds on the assimilation model of Chiswick (1978, 1979), which introduced the concept of international skill transferability. Migrants often lack skills specific to their destination country that would permit their home-country human capital to be fully valued - "transferred" - to the host-country labor market. As English and other U.S.-specific skills or credentials are gained, the value of the immigrant's home-country human capital is restored: the aerospace engineer, who could not get a job in aerospace engineering, or even engineering, now lands a job in his field.

The IHCI model highlights two aspects of immigrant skill transferability. One, immigrants whose home-country skills do not transfer fully to the new labor market will have lower wages and hence a lower opportunity cost of human-capital investment than otherwise similar natives or immigrants with high skill transferability: The time they spend learning new skills, instead of applying their current skills to earning, is less costly for them than it is for natives or high-skill-transferability immigrants, who earn more with the same level of schooling and experience. Two, home-country skills that are not fully valued in the host-country labor market are useful for learning new skills. Persons who have learned one set of skills - even if those skills are not valued in the destination-country labor market—-have advantages in learning 
a new skill set: those with home-country skills have learned how to learn. Moreover, common elements between old and new skills aid learning. ${ }^{20}$ Combined, these factors imply that low-skilltransferability immigrants will have a higher propensity to invest in human capital and will do so over a longer period than otherwise similar natives or immigrants with skills that are initially more transferable.

With its emphasis on the low opportunity cost of human capital investment for immigrants lacking transferable skills, paired with the value of home-country human capital for learning new skills, a distinguishing feature of the IHCI model is its conclusion that the higher incentive to invest in human capital pertains not only to U.S.-specific human capital that restores the value of specific source-country human capital - the foreign-born aeronautical engineer who learns English so that he can pursue aeronautical engineering again — but to new human capital investment in general.

Immigrant-admission programs that seek to fill specific labor market needs will be less likely to foster a flexible labor force. An immigrant with highly transferable skills allowing him to immediately pursue a job in his field would be reluctant to undertake training in another field. This would be true even if the training facilitated an ultimately better paid line of work because of the lost wages that such training would incur. The low opportunity cost for a similarly educated kinship-based immigrant who could not initially transfer his home-country human capital, paired with the value of this undervalued human capital in producing new human capital, might make pursuing further training an attractive option.

Immigrants with family ties in the U.S. will also be more likely to stay in the U.S. than immigrants lacking U.S. kinship ties. Permanence promotes investing in U.S.-specific human

\footnotetext{
${ }^{20}$ For more discussion on this point, refer to Duleep and Regets $(1999,2002)$.
} 
capital.

Empirical evidence comparing U.S. natives with recent immigrants, most of whom were kinship-admitted, supports the theoretical expectation that family-based immigrants have a higher propensity to invest in U.S. human capital than either U.S. natives or employment-based immigrants. Earnings growth is a robust indicator of human capital investment. Studies of longitudinal data that follow individual U.S. immigrants (and do not impose any relationship between entry earnings and earnings growth) find that recent immigrant men and women start with relatively low initial earnings and then experience wage and earnings growth far exceeding that of U.S. natives (e.g., Duleep and Regets 1997a,b; Duleep and Dowhan 2002a, 2002b).

Immigrant earnings patterns characterized by low initial earnings and high earnings growth are associated with high rates of schooling, training, and occupational change (Duleep and Regets 1999, 2002, Akresh 2007). Duleep and Regets (1999) find that adult immigrants are more likely to be enrolled in school and at older ages than natives. Green (1999) finds a greater propensity of immigrants to change occupations than natives beyond what can be explained by an assimilation effect; the timing of the changes across year-of-entry cohorts suggests that they are in response to an evolving demand for different types of labor-market skills.

Comparing immigrants by admission category further confirms the high earnings growth of kinship-based immigrants. Using 1965 to 1990 Immigration and Naturalization Service (INS) data on admissions matched to 1980 and 1990 census data, Duleep and Regets (1992, 1996a, b) find that family-based immigrants have low initial earnings but high earnings growth relative to immigrants admitted on the basis of occupational skills. Jasso and Rosenzweig (1995) find that the initial gap in the occupational attainment of employment-based and kinship-based 
immigrants lessens considerably with time in the United States.

The IHCI model also predicts that the greater propensity to invest of kinship-admitted versus employment-admitted immigrants (and more generally of low-skill-transferability versus high-skill-transferability immigrants and of immigrants versus natives) increases with education. In most human capital models, prior education has an ambiguous effect upon investment decisions: An increase in an individual's education increases both the opportunity cost of time spent in human capital investment and the productivity of that time. In the IHCI model, sourcecountry human capital that is not valued in the destination-country labor market is useful for gaining new skills. Yet, because it is not valued in the host-country's labor market, it does not increase the opportunity cost of time spent in human capital investment.

Consistent with the IHCI model, Duleep and Regets (2002) find that the earnings growth of the more educated versus the less educated is higher among immigrants coming from economically developing countries than it is for immigrants coming from economically developed countries. Moreover, when Duleep and Regets (1996a) interact education with admission status, they find that the higher earnings growth rate of kinship versus employmentbased immigrants increases with education.

With this theoretical perspective we would expect that immigrants lacking immediately transferable skills, particularly the highly educated, would foster entrepreneurship by native Americans. Duleep, Jaeger, and Regets (2012) find that concentrations of highly educated recent U.S. immigrants across time and space positively correlates with business development by U.S. natives. 


\section{Siblings and Immigrant Business Formation}

In addition to providing a flexible labor force that facilitates entrepreneurship and new directions by U.S. natives, immigrants can be entrepreneurs themselves. Here, again, kinshipadmitted immigrants play a productive role. In research examining the likelihood that an Asian or Hispanic immigrant starts a business, Duleep and Regets (1996b) found that the most important predictor, dwarfing all other variables such as years of schooling and age, was whether an immigrant had siblings in the U.S.

The prominence of siblings in predicting immigrant entrepreneurship may reflect a strategy in which family members support the investment of other family members in order to maximize family income over time. A similar phenomenon may occur in extended families. Khandewal (1996), Jiobu (1996), and Kim and Hurh (1996) give evidence of extended families and close-knit immigrant communities fostered by kinship ties supporting immigrant investment activities. Portes and Bach (1985), Waldinger (1986), Bailey (1987), and Gallo and Bailey (1996) document an immigrant sector in various industries characterized by mutually beneficial arrangements between recent immigrants and longer term immigrants in which recent immigrants working as unskilled laborers at low wages (or even no wages) in immigrant-run businesses are provided training and other forms of support that eventually lead to more skilled positions or self-employment. The development of kinship-based immigrant communities in the United States should also increase the permanence of immigrants; a longer time horizon promotes long-term investment behavior characterized by low initial earnings and high earnings growth.

All of these factors - skill transferability, the extent of social capital associated with 
denser family and community ties, and permanence - would be expected to contribute to greater investment in U.S.-specific human capital by family-admitted immigrants.

\section{Other Benefits of Education and a Caveat}

The preceding discussion suggests that for immigrants coming in without immediately transferable skills, as would be the case for many kinship-based immigrants, there is a high propensity to invest in new human capital and that this tendency increases with education. Education confers other benefits as well.

Education imparts an earnings advantage that persists over the life cycle of immigrants. Indeed, for adult immigrants younger than 40 , the effect of education on earnings is most apparent in the long run. Table 1 shows the earnings ratio of immigrants with more than 12 years of schooling to those with 12 years or less at entry and ten years later. For both the cohorts who entered in 1965-69 and in 1975-79, the beneficial effect of education on earnings increases markedly with time in the United States for immigrants from all source regions. Among immigrants in the more recent cohort, the initial earnings of the more educated immigrants exceed the earnings of less educated immigrants by 30 percent. Ten years later, the earnings of the more educated are double those of the less educated.

The beneficial effects of education are also multifaceted. Chiswick and Miller (1996) find a strong and positive association between education and proficiency in host-country language proficiency. Their robust results lead them to note that an admissions policy that selects immigrants who are young and better educated would also select "immigrants who have, or who can be expected to acquire quickly, official language skills." Simon and Akbari (1996) find that education 
is an important determinant of immigrant welfare use: holding constant other variables, halving

schooling more than doubles transfers received.

The presumed advantage of more educated immigrants is not, however, without

qualification. Bhagwati (1996, p. 327) notes:

...if we were to consider the question instead in terms of who should be admitted so as to maximize the beneficial impact on those who are already the natives and residents of the United States, the answer must focus instead on whether the social marginal product in the United States of these alternative migrants exceeds their own private returns and, if so, which group offers the greater such excess.... The answer is no longer easy or obvious.....Thus consider whether the entry of one more Filipino doctor practicing on Park Avenue in New York will produce more benefits for us than the entry of one Haitian maid-cum-child-care provider on the Upper West Side in the same city. In a society where child care is underprovided and where the participation of middle-class women in the work force is a value in itself, the Haitian immigrant could well imply greater net social benefits to us than the entry of one more doctor who settles in a high-income urban area, earns close to the value of his or her social marginal product, and contributes little net income to the rest of us. Unfortunately, none of the advocates of skilled immigration have analyzed such issues.

Moreover, if Echautegui (1995) and Lewis (2007) are right, and firms respond to lowskilled immigration in ways that alter the skill-level mix of available jobs (as discussed in Part I), then closing off legal and illegal pathways for the poorly educated to enter the U.S. might have the unintended consequence of reducing low-skilled employment opportunities for poorly educated U.S. natives and residents.

\section{Insights from Canadian Experiences}

To the extent that U.S. policy makers want to increase the skill levels of immigrants, an attractive route would be to give points for kinship ties and education both of which appear to have persistent economic benefits for immigrant economic assimilation and a dynamic economy. Insights from other countries may elucidate how various policy alternatives could affect $—$ or fail to affect - the educational composition of immigrants. 
Prior to 1993, the Canadian system departed from the American system in that admission decisions for numerically restricted immigrants were based on a point system that primarily reflected productivity characteristics: characteristics believed to promote the economic assimilation of immigrants in general, such as youth, education, and greater proficiency in English (or French), and characteristics, regardless of skill level, that were tailored to prevailing demand conditions of the Canadian economy, such as particular occupational backgrounds in high demand.

Despite Canada's greater emphasis on education in its admissions policy, Duleep and Regets (1992) found the education levels of Canadian and U.S. immigrants from the same region of origin to be similar. Borjas (1993) stressed the effect of the Canadian skills-based system on the country-of-origin composition of immigrants which in turn affected immigrant education levels. However, a historical comparative analysis of Canadian and U.S. immigration suggests that his analysis attributes to the Canadian skills-based policy, imposed in the 1960s, what is likely due to the proximity of the United States to Central and South America and the historically much higher European representation in Canadian immigration. The question should be whether European immigration fell less in Canada and Central and South American immigration increased less in Canada than in the United States following imposition of Canada's skills based admissions policy. Although European immigration decreased from the 1960s to the 1970s in both countries, as a percentage of past immigration, it decreased more in Canada; immigration from Central and South America increased in Canada, whereas it decreased in the U.S.

In 1993, Canadian immigration policy evolved from a system that sought to achieve multiple objectives by giving points to prospective immigrants for a wide variety of attributes to 
one that simply gives points to immigrants for their level of schooling (the higher their schooling, the more points), youthfulness, and language proficiency in English or French. Beach and Green (2005) write:

...there was a major change in the point system...away from specific occupational preferences and towards broader emphasis on educational credentials, language facility and young families... with an eye to human capital and skill development of the host country.

An important aspect of the Canadian system's simplification was its abandonment of a policy of tailoring immigration to fill various perceived employment needs. As Beach and Green note,

...the weighting scheme [of the earlier system] ... focused on occupational needs in the economy at a particular point of time.... The occupational-based or gap-filling model used to guide admission was changed in the mid-nineties. In its place was substituted an earnings or human capital model perspective. Under this approach, specific occupational needs were reduced in the weighting scheme while additional points were awarded to education, age and language... This shift in weights in Canada signaled a move towards a longer-run view of immigration policy.

Beach and Green (2005) find that following the change, a huge increase in the educational level of Canadian immigrants occurred. Theoretically, this is what one would expect. As more objectives in an immigrant admission point system are added to the educational enhancement objective, the effectiveness of the educational enhancement objective is reduced. By dropping its emphasis on immigration as a tool for filling particular perceived labor shortages, the educational objective of the Canadian point system was enhanced. Quebec experienced less of an improvement in immigrant educational attainment than was true of the rest of Canada, perhaps reflecting a dilution of the educational objective with its greater emphasis on host-country language facility (Parent and Worswick, 2003; Beach and Green, 2005). 


\section{CONCLUSION}

U.S. immigration policy is at a crossroads in two respects. One is what should the U.S. do about undocumented immigration and more generally the immigration of poorly educated individuals? The other is, should we continue with the family-based immigration system that has been the foundation of U.S. immigration since 1965, or adopt a more skills-based system for admitting immigrants?

The interest in reforming the U.S. immigration system from a primarily family-based system to one based more on the specific occupational skills of individuals stems from concerns about the "quality" of recent immigrants — do they productively contribute to the economy? —as well as their impact on the jobs and wages of U.S. natives.

Kinship-based immigration is typically justified on humanitarian grounds. The general belief that immigrants admitted on the basis of occupational skills are more economically productive than immigrants admitted via family ties has been a key motivating factor in calls to reduce kinship-based immigration and increase employment-based immigration.

Nevertheless, kinship-based immigrants do contribute to the economy in important ways that have been underappreciated. Several analyses suggest that controlling for level of schooling, family-based immigrants may compete less with natives and at the same time contribute in ways that bolster the U.S. economy's vitality. Recent immigrants - the majority of whom enter the U.S. on family visas - are meeting the challenges of a U.S. labor market through melding high rates of post-migration human capital investment to their original skills. Rather than contributing to an underclass, they have become the most upwardly mobile of American workers. This greatly benefits both immigrants and the U.S. economy. Moreover, by adopting a less family-friendly admission 
system, the U.S. may become less attractive to highly-skilled immigrants, who have families too.

In the march to reform U.S. immigration, a principle focus has been to increase employment-based immigration at the expense of family-based immigration. A better approach for increasing the skill level of U.S. immigrants would be to replace the fill-the-gap employment-based system, which requires a bureaucracy to execute an impossible mission, with an increased emphasis on education. Doing so could potentially increase the vital force that kinship-based immigrants provide to the U.S. economy. One approach for an increased emphasis on education would be to give points for schooling levels, bearing in mind that the larger the number of attributes to which points are given, the more dilute an education effect will be.

Another minimally bureaucratic approach for increasing education levels of immigrants in a way that promotes a flexible labor force, is a student stay-on policy proposed by Jagdish Bhagwati (1996, p. 328):

[A] policy option that would enable us to tap both skilled immigrants and to earn returns on our educational investment is to facilitate the possibility of foreign students staying on as immigrants. At the moment, several do but the process is difficult and almost uphill for many. By certifying several colleges and universities, and their higher degrees, as sufficient conditions for seeking immigrant visas, and enlarging the quota numbers to an elastic amount determined by the applications themselves, we can both eliminate the difficulties imposed on our foreign graduates as they struggle to stay here and also resolve to our advantage the "crisis" that is the stuff of media articles on how in mathematics, sciences, and engineering, there is now a large and growing body of foreign rather than native students. The distinction between foreign and native students would cease to matter, as indeed it can, if only the foreign students were seen as potential stay-ons in our society of immigrants.

With regard to undocumented immigration and more generally the immigration of the poorly educated, the jury is still out on whether poorly educated immigrants harm, help, or have no effect on the wages and employment opportunities of poorly educated U.S. natives. This paper suggests a way to get out of this unfortunate muddle. If it is convincingly found that the immigration of poorly educated individuals hurt the economic opportunities of U.S. natives, then 
this might be another reason for adding the education of potential immigrants to the admission matrix.

An insight that prevails in microanalyses and in historical analyses of groups is that expected permanence is a key ingredient for human capital investment by immigrants in U.S.specific human capital. With continued immigration of the poorly educated—via legal, illegal, or temporary-worker avenues — consideration should be given to the importance of being permanent in promoting economic mobility for immigrants and their children. 


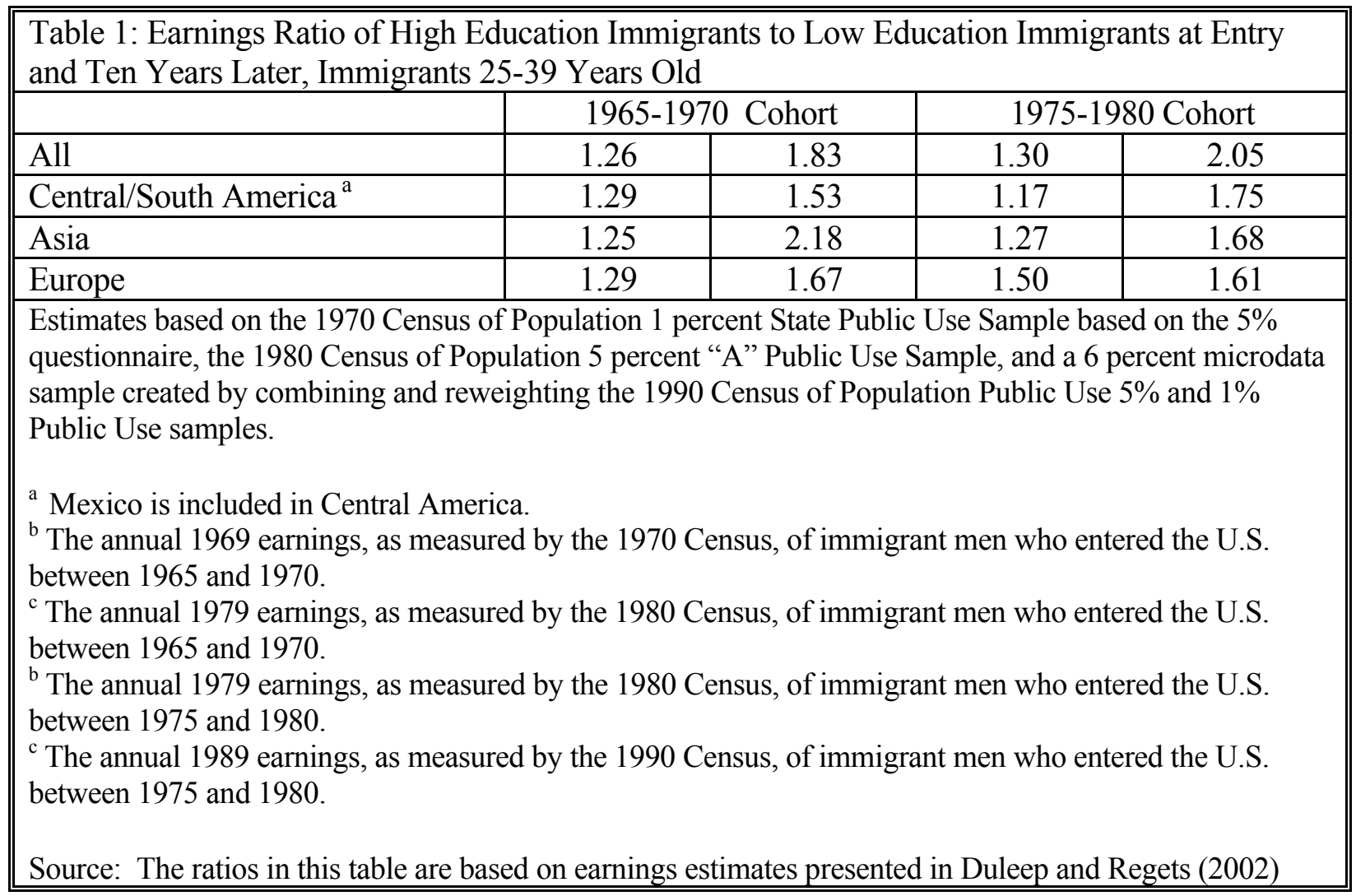




\section{References}

Akresh, I.R. 2007. 'U.S. Immigrants' Labor Market Adjustment: Additional Human Capital Investment and Earnings Growth.” Demography, 44(4): 865-881.

Altonji, Joseph G. and David Card, 1991. "The Effects of Immigration on the Labor Market Outcomes of Less-skilled Natives." In Immigration, Trade, and the Labor Market edited by John M. Abowd and Richard B. Freeman, pp. 201-234 National Bureau of Economic Research, Chicago: University of Chicago Press.

Aydemir, Abdurrahman and George Borjas. 2011. "Attenuation Bais in Measuring the Wage Impact of Immigration,” Journal of Labor Economics, Vol. 29, No. 1, January, pp. 69112.

Bailey, Thomas R. 1987. Immigrant and Native Workers: Contrasts and Competition, Conservation of Human Resources, Boulder and London: Westview Press.

Bailey, Thomas R. and Roger Waldinger. 1991. "Primary, Secondary, and Enclave Labor Markets: A Training Systems Approach,” American Sociological Review, vol. 56, August, 432445.

Bartel, Ann P. 1989. "Where Do the New U.S. Immigrants Live?” Journal of Labor Economics, vol. 7, no. 4, pp. 371-391

Beach, Charles M. and Alan G. Green, "The Impacts of the Point System and Immigrant Class on Skill Characteristics of Immigrant Inflows: The Experience of Canada," paper presented at the Conference on Immigration: Trends, Consequences and Prospects for the United States," September 2005.

Beach, Charles M., Alan G. Green, and Christopher Worswick "Impacts of the Point System and Immigration Policy Levers on Skill Characteristics of Canadian Immigrants" in in Immigration:Trends, Consequences and Prospects for the United States, ed. Barry R. Chiswick, IZA, Elsevier, JAI 2008, 349-401.

Bhagwati, Jagdish, 1996. "U.S. Immigration Policy," in Harriet Duleep and Phanindra V. Wunnava (editors), Immigrants and Immigration Policy: Individual Skills, Family Ties, and Group Identities, Greenwich, CT: JAI Press, 323-334.

Borjas, George J. 1993. "Immigration Policy, National Origin, and Immigrant Skills: A Comparison of Canada and the United States," in David Card and Richard B. Freeman, Small Differences That Matter: Labor Markets and Income Maintenance in Canada and the United States University of Chicago Press, 21-44. 
Borjas, George J., Richard B. Freeman, and Larry F. Katz. 1992. “On the Labor Market Impacts of Immigration and Trade," in G.J. Borjas and R.B. Freeman (editors), Immigration and the Work Force, National Bureau of Economic Research, Chicago: The University of Chicago Press, 213-244.

Card, David. 1990. The Impact of the Mariel Boatlift on the Miami Labor Market, Industrial and Labor Relations Review, vol. 43, January, pp. 245-57.

Chiswick, Barry. 1978. "The Effect of Americanization on the Earnings of Foreign-born Men." The Journal of Political Economy 86(5): 897-921.

—. 1979. The Economic Progress of Immigrants: Some Apparently Universal Patterns. In Contemporary Economic Problems edited by William Fellner, 359 399. Washington, D.C.: American Enterprise Institute.

- 1980. An Analysis of the Economic Progress and Impact of Immigrants. Department of Labor monograph, (No. PB80-200454), Washington, DC: Technical Information Service.

—. 1981. "Guidelines for the Reform of Immigration Policy," in W. Fellner (Ed.), Essays in Contemporary Economic Problems: Demand, Productivity, and Population, Washington DC, American Enterprise Institute for Public Policy Research, 309-347.

Chiswick, Barry and Miller, Paul W. 2002. "The Complementarity of Language and Other Human Capital: Immigrant Earnings in Canada.” Discussion Paper No. 451, IZA

Congressional Research Service. 1980. "Temporary Worker Programs: Background and Issues," U.S. Senate, Ninety-sixth Congress, Second Session, Committee on the Judiciary, Washington, D.C.: U.S. Government Printing Office, February.

Duleep, Harriet Orcutt. 1988. The Economic Status of Americans of Asian Descent, with Seth Sanders, U.S. Commission on Civil Rights, March http://www.eric.ed.gov/PDFS/ED309210.pdf

-. 2012. "One Way the Demand for Labor May Adapt to the Availability of Labor," IZA Discussion Paper, no. 6686, http://www.iza.org/en/webcontent/publications/papers/viewAbstract?dp id=6686

-. 2012. "Sharpening the Effectiveness of Natural Experiments as an Analytical Tool," IZA Discussion Paper, no. 6682 http://www.iza.org/en/webcontent/publications/papers/viewAbstract?dp id=6682

Duleep, Harriet Orcutt and Daniel Dowhan. 2002a. "Insights from Longitudinal Data on the Earnings Growth of U.S. Foreign-born Men.” Demography 39: 485-506. 
—. 2002b. "Revisiting the Family Investment Model with Longitudinal Data: The Earnings Growth of Immigrant and U.S.-Born Women," with Daniel Dowhan, IZA Discussion Paper, no. 568, http://www.iza.org/en/webcontent/publications/papers/viewAbstract?dp id=568

Duleep, Harriet Orcutt, David Jaeger and Mark Regets. 2012. "How Immigration May Affect the Entrepreneurship of Natives: Theoretical Building Blocks and Preliminary Results," IZA Discussion Paper 6677 http://www.iza.org/en/webcontent/publications/papers/viewAbstract?dp id $=6677$

Duleep, Harriet Orcutt and Mark C. Regets. 1992. "Some Evidence on the Effect of Admission Criteria on Immigrant Assimilation," in Immigration, Language and Ethnic Issues: Canada and the United States, Barry Chiswick (ed.). Washington, D.C.: American Enterprise Institute, 410-439.

—. 1996a. "Admission Criteria and Immigrant Earnings Profiles," International Migration Review, Summer.

—. 1996b. "Family Unification, Siblings, and Skills," in Harriet Duleep and Phanindra Wunnava (eds.), Immigrants and Immigration Policy: Individual Skills, Family Ties, and Group Identities, Greenwich, CT: JAI Press, 219-244.

—. 1997a. "The Decline in Immigrant Entry Earnings: Less Transferable Skills or Lower Ability?" Quarterly Review of Economics and Finance, 37, Special Issue on Immigration, 189208.

—. 1997b. "Measuring Immigrant Wage Growth Using Matched CPS Files." Demography 34 (2) May, 239-249. May, 186-191.

—. 1999. "Immigrants and Human Capital Investment," American Economic Review,

—. 2002. "The Elusive Concept of Immigrant Quality: Evidence from 1970-1990," IZA Discussion Paper, no. 631, http://www.iza.org/en/webcontent/publications/papers/viewAbstract?dp id=631

Duleep, Harriet Orcutt and Seth Sanders. 1994. "Empirical Regularities across Cultures: The Effect of Children on Women's Work," Journal of Human Resources, Spring, pp. 328-47

Enchautegui, Maria E. 1995. "Immigrants and the Low-Skilled Market," Program for Research on Immigration Policy, Discussion Paper. Washington, DC: The Urban Institute.

Fertig, Michael, and Christoph M. Schmidt. 2001. "Aggregate-level Migration Studies as a Tool for Forecasting Future Migration Streams.” In Slobodan Djajic (ed.), International Migration: Trends, Policy and Economic Impact, London/New York, 110-136. 
Fix, Michael and Jeffrey S. Passel. 1994. Immigration and Immigrants: Setting the Record Straight, Washington, DC: The Urban Institute.

Gallo, Carmenza and Thomas R. Bailey. 1996. "Social Networks and Skills-Based Immigration Policy," in Harriet Duleep and Phanindra V. Wunnava (editors), Immigrants and Immigration Policy: Individual Skills, Family Ties, and Group Identities, Greenwich, CT: JAI Press, 203-18.

Gang, Ira N. and Francisco L. Rivera-Batiz. 1994. "Labor Market Effects of Immigration in the United States and Europe: Substitution vs. Complementarity." Journal of Population Economics 7(2): 157-175.

Green, David A., "Immigrant Occupational Attainment: Assimilation and Mobility Over Time," Journal of Labor Economics, vol. 17, no. 1, January 1999, 49-79.

Haines, Michael R. 1989. "Consumer Behavior and Immigrant Assimilation: A Comparison of the United States, Britain, and Germany 1889/1890," Working Paper No. 6, Working Paper Series on Historical Factors and Long Run Growth, Cambridge, Mass: National Bureau of Economic Research.

Hatton, Timothy J. and Jeffrey G. Williamson. 1992. "International Development and World Migration: A Historical Perspective.” NBER Historical Paper no. 41, Cambridge, MA: National Bureau of Economic Research.

_, 1994. Migration and the International Labor Market, 1850-1939. London: Routledge.

—, 1995. "The Impact of Immigration on American Labor Markets Prior to the Quotas," Working Paper No. 5185, Cambridge, Mass.: National Bureau of Economic Research.

Hoefer, Michael, Nancy Rytina, and Bryan C. Baker. 2010. Estimates of the Unauthorized Immigrant Population Residing in the United States: January 2009. Washington DC: Office of immigration Statistics, U.S. Department of Homeland Security.

Hourwich, I. 1922. Immigration and Labor: The Economic Aspects of European Immigration to the United States (2nd Edition) New York: Huebsch.

Hunt, Jennifer. 1992. "The Impact of the 1962 Repatriates from Algeria on the French Labor Market.” Industrial and Labor Relations Review 45(3): 556-572.

Jaeger, David A. 1996. "Skill Differences and the Effect of Immigration on the Wages of Natives," Bureau of Labor Statistics Working paper 273. 
Jiobu, Robert M. 1996. "Explaining the Ethnic Effect," in Harriet Duleep and Phanindra V. Wunnava (editors), Immigrants and Immigration Policy: Individual Skills, Family Ties, and Group Identities, Greenwich, CT: JAI Press, 103-114.

Jasso, Guillermina and Mark R. Rosenzweig. "Do Immigrants Screened for Skills Do Better than Family-Reunification Immigrants?” International Migration Review, vol. 29, no. 1, $1995,85-111$.

Jencks, J.W. and W.J. Lauck. 1926. The Immigration Problem, (6th edition) New York: Huebsch.

Jiobu Robert M. 1996. "Explaining the Ethnic Effect," in Immigrants and Immigration Policy: Individual Skills, Family Ties, and Group Identities, edited by Harriet Duleep and Phanindra V. Wunnava. Greenwich, Conn.: JAI Press, 103-114.

Khandelwal, Madhulika. 1996. "Indian Networks in the United States: Class and Transnational Identities," in Harriet Duleep and Phanindra V. Wunnava (editors), Immigrants and Immigration Policy: Individual Skills, Family Ties, and Group Identities, Greenwich, CT: JAI Press, 115-132.

Kim, Kwang Chung and Won Moo Hurh. 1996. "Ethnic Resources Utilization of Korean Immigrant Entrepreneurs in the Chicago Minority Area," in Harriet Duleep and Phanindra V. Wunnava (editors), Immigrants and Immigration Policy: Individual Skills, Family Ties, and Group Identities, Greenwich, CT: JAI Press, 149-174.

Lewis, Ethan. 2011. "Immigration, Skill Mix and Capital-Skill Complementarity," Quarterly Journal of Economics, vol. 126 (2), 2011.

Lewis, Staughton Y. 1994. "Impacts of Immigrants on U.S. Natives' Employment and Earnings: A Summary of the Evidence," in Espenshade, Thomas J. (editor) A Stone's Throw from Ellis Island: Economic Implications of Immigration to New Jersey, Lanham, New York, London: University Press of America.

Lowell, B. Lindsay. 1996. "Skilled and Family-Based Immigration: Principles and Labor Markets," In Immigrants and Immigration Policy: Individual Skills, Family Ties, and Group Identities edited by Harriet Duleep and Phanindra V. Wunnava, Greenwich, CT: JAI Press, 353-371.

Manson, Donald M., Thomas Espenshade, and Thomas Muller. 1985. "Mexican Immigration to Southern California: Issues of Job Competition and Labor Mobility. Review of Regional Studies 15: 21-33.

Massey, Douglas S. 1990. "The Social and Economic Origins of Immigration." The Annals 510:60-72. 
-. 2011. "Chain Reaction: The Causes and Consequences of America's War on Immigrants," Julian Simon Lecture Series, paper presented at Annual Migration Meeting, IZA, May.

Massey, D. S., and R. M. Zenteno. 1999. "Dynamics of Mass Migration," Proceedings of the National Academy of Sciences 96(6): 5328-5335.

Modell, John. 1978. "Patterns of Consumption, Acculturation, and Family Income Strategies in Late Nineteenth Century America," in T.K. Hareven and M.A. Vinovskis, eds. Family and Population in Nineteenth-Century America. Princeton, NJ: Princeton University Press: 206-240.

Muller. Thomas and Thomas J. Espenshade. 1985. The Fourth Wave: California's Newest Immigrants. Washington. DC: The Urban Institute Press.

Ottaviano, Gianmarco and Giovanni Peri, 2006. "Rethinking the Effects of Immigration on Wages," Working Paper 12497, NBER, August.

Parent, Daniel and Christopher Worswick. 2003. "Qualificaitons et Immigrations: Réforme de la Grille d'Admissions du Québec et Composition de la Population d'Immigrants s'Etablessant au Québec," Research Paper prepared for the Department of Finance, Government of Québec.

Peri, Giovanni \& Sparber, Chad. 2011. "Task Specialization, Immigration, and Wages," American Economic Journal: Applied Economics, 1:3, 135-169.

Piore, Michael J. 1979. Birds of Passage: Migrant Labor and Industrial Societies, New York: Cambridge University Press

Portes, Alejandro and Robert L. Bach, Latin Journey: Cuban and Mexican Immigrants in the United States, Berkeley: University of California Press, 1985.

Rivera-Batiz , Francisco L. 1999. "Undocumented Workers in the Labor Market: An Analysis of the Earnings of Legal and Illegal Mexican Immigrants in the United States," Journal of Population Economics, 12:91-116

Sanders, Jimy. 2012. "Complement or Competition: Latino Employment in a Nontraditional Settlement Area," Social Science Research, 41, September, 48-60.

Simon Julian L. and Ather H. Akbari. 1996. "Determinants of Welfare Payment Use by Immigrants and Natives in the United States and Canada," in Harriet Duleep and Phanindra V. Wunnava (editors), Immigrants and Immigration Policy: Individual Skills, Family Ties, and Group Identities, Greenwich, CT: JAI Press, 79-102 
Sorensen, Elaine. 1996. "Measuring the Employment Effects of Immigrants with Different Legal Statuses on Native Workers," in Harriet Duleep and Phanindra V. Wunnava (eds.), Immigrants and Immigration Policy: Individual Skills, Family Ties, and Group Identities, Greenwich, CT: JAI Press, 245-264.

U.S. Census Bureau. 1996. Population Projections of the United States by Age, Sex, Race and Hispanic Origin: 1995-2050. Current Population Reports P25-114 Washington, DC: U.S. Census Bureau.

Vogler, M., and R. Rotte. 2000. "The Effects of Development on Migration: Theoretical Issues and New Empirical Evidence,” Journal of Population Economics, 13(3): 485-508.

Waldinger, Roger. 1986. Through the Eye of the Needle: Immigrant Enterprise in New York’s Garment Trades, New York, N.Y.: New York University Press.

—. 1996. Who Makes the Beds? Who Washes the Dishes? Black/Immigrant Competition Reassessed. In Immigrants and Immigration Policy: Individual Skills, Family Ties, and Group Identities, edited by Harriet Duleep and Phanindra V. Wunnava Greenwich, CT: JAI Press, 265-288. 